\title{
Relationships between land use, predicted pollution loadings, and ecotoxicological assays in constructed wetlands
}

https://doi.org/10.21698/rjeec.2020.215

Proceedings Paper

\author{
SUBHOMITA GHOSH ROY ${ }^{1 *}$, TIMOTHY J. EHLINGER ${ }^{1,2}$ \\ ${ }^{1}$ Department of Biological Sciences, University of Wisconsin - Milwaukee, PO Box 413, Milwaukee 53201-0413, USA \\ ${ }^{2}$ Institute for Systems Change and Peacebuilding, University of Wisconsin Milwaukee, PO Box 413, Milwaukee 53201 - \\ 0413, USA \\ *Corresponding author (e-mail): subhomitagr@gmail.com
}

\begin{abstract}
Environmental degradation related to uncontrolled development resulted in the passage of the United States Clean Water Act (CWA) in 1972, with the stated purpose "to restore and maintain the integrity of the nation's waters". Implementation of the CWA leads to increased research to develop multimetric indicators to better measure and understand the complex patterns of ecological responses to stress occurring across levels of biological, spatial, and temporal organization. One area of research is the use of integrated indices of chemical risk, ecotoxicological risk, and ecological risk to assess the impact of human activity across disturbance gradients of urbanization. Selecting relevant metrics for constructing a multimetric index requires identifying bioindicator organisms with capacities to detect signals from anthropogenic disturbances. This study explored the potential efficacy of a suite of higher plant ecotoxicological assays for use as bioindicators in ecological risk assessment along a gradient of urbanization in a wetland ecosystem. The study was conducted in the Pike River watershed (Racine, Wisconsin, USA) in six wetlands selected across a gradient of dominant land use types (agricultural, commercial, residential, undeveloped, and industrial). MicroBioTest Phytotoxkit ${ }^{T M}$ ecotoxicological assays, based on growth inhibition of three plants (Sinapis, Sorghum, and Lepidium) were used to assess sediment toxicity. The relationships between Phytotoxkit ${ }^{\mathrm{TM}}$ responses and predicted pollutant loadings calculated from surrounding land use provided clear signals of stress from watershed pollutants draining into the wetland sites. The potential for these ecotoxicological indicators to serve as biological response signatures is strong, and further research and calibration in field and microcosms studies will assist in calibrating responses for use in integrated monitoring efforts.
\end{abstract}

Keywords: bioindicators, ecotoxicology, ecological risk assessment, pollutant loading, wetlands

\section{INTRODUCTION}

Urbanization is one of the major drivers of degraded surface water quality [1], attributable to increasing impervious surface area contributing to higher stormwater runoff into local streams, rivers, lakes, and wetlands [2]. This runoff in turn carries increased concentrations and loadings of nutrient and heavy metal pollutants contributing to a deterioration in the quality of the receiving waters [3] (Fig. 1). Increased public awareness of the interconnections between changes in land cover and surface water quality contributed to the passing of the US Clean Water Act (CWA) in 1972, establishing quality standards for surface waters and setting limits for the discharge of pollutants and excess nutrients [4, 5]. But CWA created a challenge for bridging the gap between the science of environmental monitoring, social-ecological domains of designated uses (e.g. fishable-swimmable), and the interconnected biogeochemical cycles affecting protective numerical criteria (e.g. phosphate standards) [6]. To this end, it became imperative to incorporate diverse disciplinary perspectives in the selection of metrics and indicators for use in monitoring programs [7].

The U.S. Environmental Protection Agency (USEPA) initially promoted the use of monitoring strategies that integrated metrics of water quality parameters, whole-effluent toxicity testing, and ambient biological assays [8]. This "3-legged stool" approach has proven to be limited in its capacity to characterize ecological integrity across diverse environmental contexts [9-11]. To develop more effective and robust monitoring strategies, the use of biological assays and bioindicators has increased steadily $[8,9]$. Concurrent with 
the increase in available tools and data, analytical approaches have increasingly focused on detecting "biological response signatures" [10] as a way to characterize the complex patterns of ecological responses to stress occurring across levels of biological, spatial, and temporal organization [7].

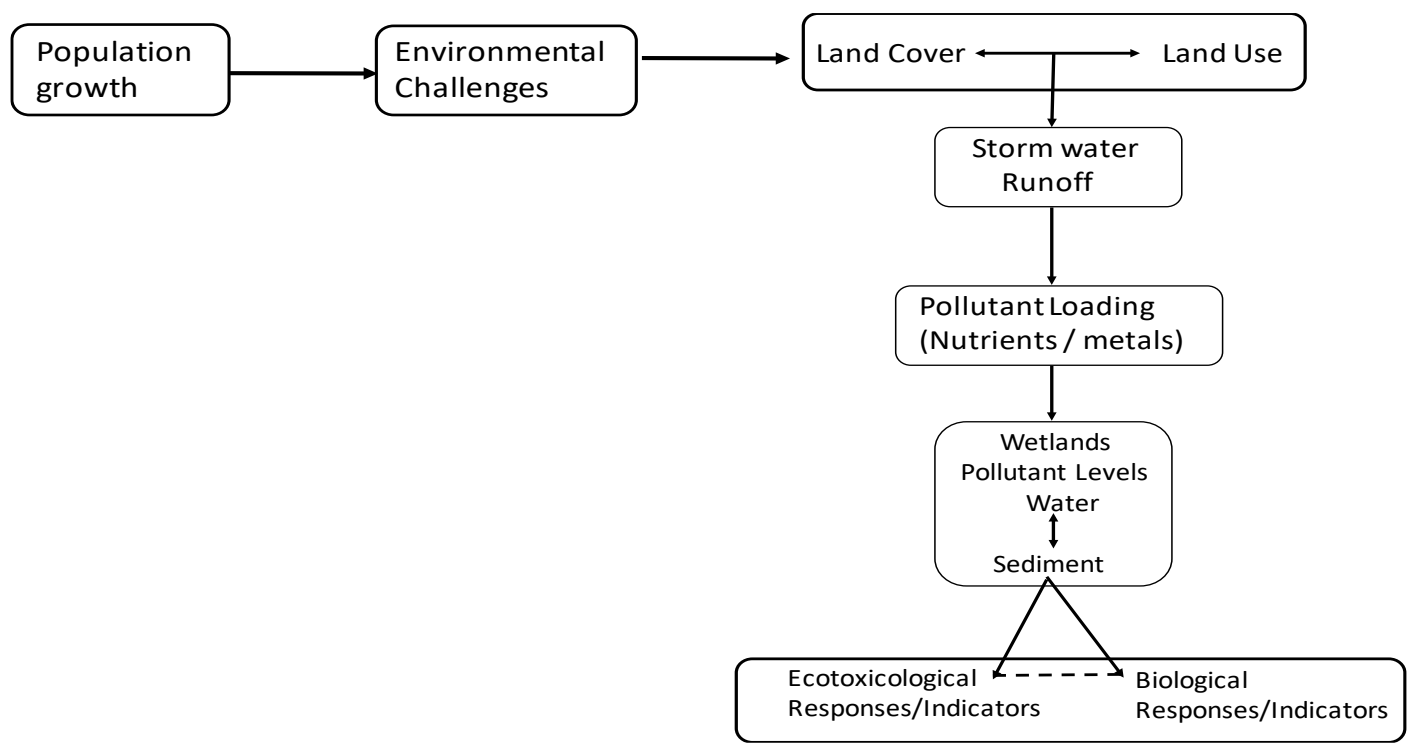

Fig. 1. Hierarchy of factors affecting the characterization of land cover and land use on ecotoxicological and bacteriological bioindicators in wetland sediments

In a study, Yoder and Rankin used the term "biological response signatures" to describe the variety of ways that indicators in aquatic ecosystems may respond to different types of environmental stressors [10]. Their work reframes the question away from looking for distinct cause-effect relationships towards identifying signals of response amidst the complex noise of potential causes $[12,13]$.

Ecological Risk Assessment approaches have been used extensively for both monitoring the effects of development (ex-post impact assessment) and predicting the likely effects of proposed projects (ex-ante impact assessment). To this end, constructed wetlands are often used to address water quantity and quality problems and mitigate the environmental impacts of historical urbanization and minimize the impact of new construction [14]. In addition to capturing sediment and pollutants that flow off surrounding landscapes [15], constructed stormwater wetlands can play a critical role in managing nutrients generated from agricultural and urban runoff [16-18]. Besides, constructed wetlands are effective in reducing heavy metal contamination generated from industrial sources [19-21].

Biomonitoring is measuring and evaluating the conditions of a living system [22]. Since the passage of CWA, biomonitoring has become an essential component for monitoring the ecological integrity and condition of watersheds [22] and bioindicators developed to serve as tools for assessing attainment of and adherence to water quality standards [10]. Bioindicators developed for wetland sediments are particularly sensitive in detecting ecological changes in watersheds $[23,24]$ and for conducting sediment risk assessments from pollutants such as metals or nutrients [25-27].

This present paper investigates the efficacy of the Phytotoxkit ${ }^{\mathrm{TM}}$ [28, 29] ecotoxicological assay with plants Sorghum saccharatum, Lepidium sativum, and Sinapis alba as bioindicators of sediment toxicity among wetlands with varying land uses and associated pollutant (nutrient and metals) predicted loadings. Phytotoxkits ${ }^{\mathrm{TM}}$ measure the growth inhibition of the indicator plants, and are effective in detecting toxic hazards in sediments in reservoirs and urban canals subjected to varying levels of marked nutrients and heavy metal such as $\mathrm{Cd}, \mathrm{Cr}, \mathrm{Cu}, \mathrm{Mn}, \mathrm{Ni}, \mathrm{Pb}, \mathrm{Zn}$ contamination [30]. These Phytotoxkits ${ }^{\mathrm{TM}}$ provide low-cost, relatively easy assays to administer and have great potential for use for 
routine evaluations as bioindicators [31, 32]. The question addressed in this paper is, does variation in growth inhibition of PhytoTox ${ }^{\mathrm{TM}}$ ecotoxicological assays (Sorghum saccharatum,
Lepidium sativum, and Sinapis alba) correlate with variation in pollution-related stressors as predicted loadings estimate that enter wetlands from their surrounding watersheds?

\section{MATERIALS AND METHODS}

Study-system, land use, and site characteristics This study was conducted in the Pike River watershed (Racine County, Wisconsin USA) utilizing a series of stormwater wetlands that were constructed between 2001 and 2008 as structural features in a flood-control plan implemented by the Village of Mount Pleasant. The plan included significant modifications in channel morphology, the creation of riparian wetland-pond systems, and the installation of fish habitat along an $8 \mathrm{~km}$ stretch of the river [33-35]. The wetlands were excavated to receive runoff from adjacent catchments that comprised of a combination of agricultural, commercial, residential, undeveloped, and industrial land uses [33-35]. Six individual wetlands were selected for this study to capture a gradient of dominant land cover types (Fig. 2). The catchment area and percent land use (residential, commercial, industrial, agricultural, and undeveloped) for each wetland were determined from Southeastern Wisconsin Regional Planning Commission or SEWRPC, 2010 Racine County map book [36] and are shown in Table 1.
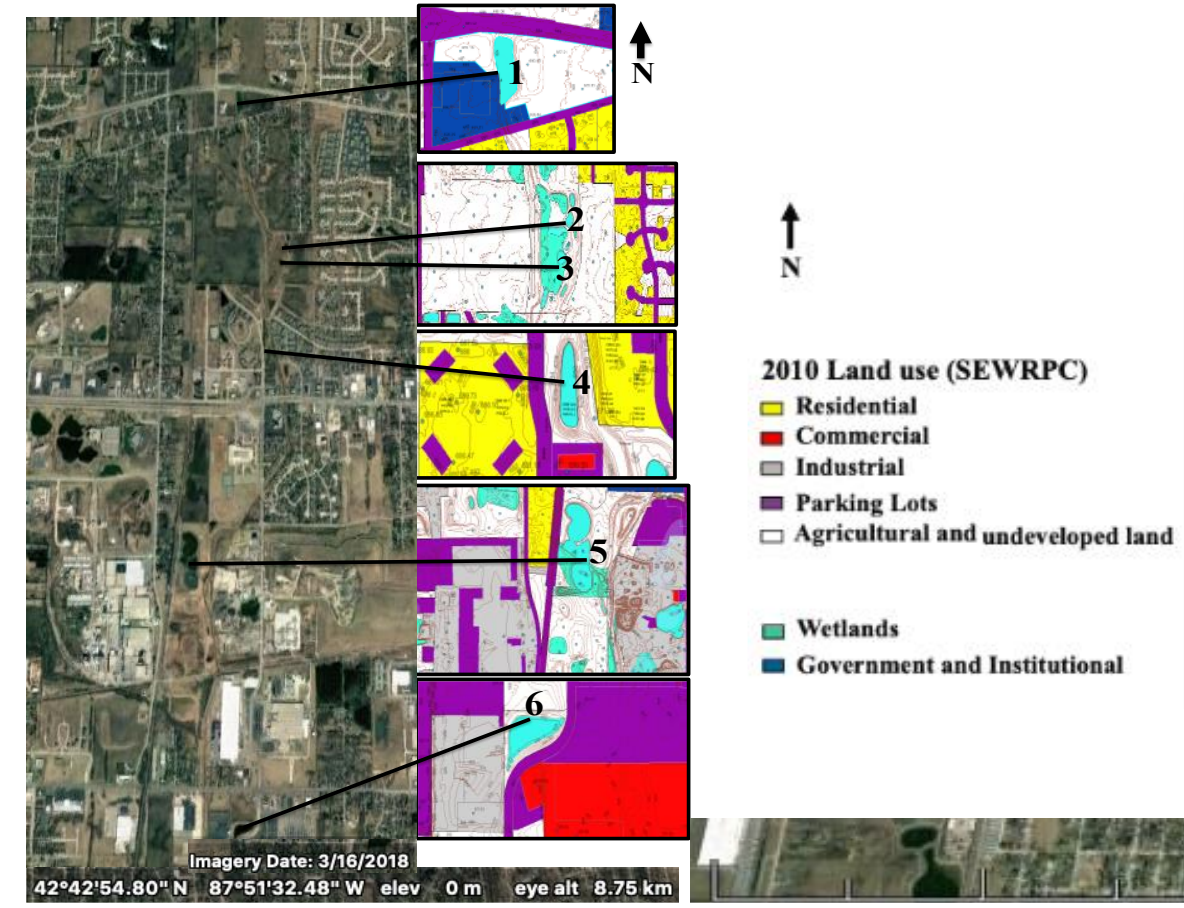

$\square$ Wetlands

- Government and Institutional

Fig. 2. Aerial photograph of the Pike River North Branch (Google 2015) showing locations $\left(42^{0} 43^{\prime} \mathrm{N}\right.$ and $87^{0} 52^{\prime} \mathrm{W}$, scale: $4.1 \mathrm{~cm}=1967 \mathrm{~m}$ ) of study wetlands and surrounding land use (Southeastern Wisconsin Regional Planning Commission, SEWRPC 2010)

Table 1. Watershed area (hectares) and cover percentages as a percent of the watershed area of wetland study sites in the Pike River watershed

\begin{tabular}{c|cccccc}
\hline \multirow{2}{*}{ Wetland site } & \multicolumn{5}{|c}{ Land Cover (Percent of Watershed) } \\
\cline { 2 - 7 } & $\begin{array}{c}\text { Watershed } \\
\text { Area (ha) }\end{array}$ & $\begin{array}{c}\text { Percent } \\
\text { Residential }\end{array}$ & $\begin{array}{c}\text { Percent } \\
\text { Commercial }\end{array}$ & $\begin{array}{c}\text { Percent } \\
\text { Industrial }\end{array}$ & $\begin{array}{c}\text { Percent } \\
\text { Agricultural }\end{array}$ & $\begin{array}{c}\text { Percent } \\
\text { Undeveloped }\end{array}$ \\
\hline 1 & 104.45 & 11.00 & 15.10 & 12.10 & 61.60 & 0.00 \\
2 & 334.18 & 42.30 & 0.00 & 0.00 & 57.50 & 0.00 \\
3 & 267.46 & 41.80 & 0.00 & 0.00 & 58.20 & 0.00 \\
4 & 2.88 & 58.90 & 6.00 & 0.00 & 35.20 & 0.00 \\
5 & 493.72 & 15.70 & 14.20 & 20.80 & 0.00 & 49.30 \\
6 & 720.00 & 0.00 & 72.20 & 20.20 & 0.00 & 7.20 \\
\hline
\end{tabular}


Pollution loading estimates

Pollutant loadings into wetland sites were estimated based upon the calculated land uses draining into each wetland. The percent land use measurements for each category within the area draining into each wetland site was provided in Source Load and Management Model or SLAMM [37], run by Village of Mount Pleasant, Racine County Wisconsin, 2011 during the construction of these wetlands (Fig. 3 and 4). By default, agricultural lands were incorporated into the category of the undeveloped land in SLAMM, due to its use as an urban planning model $[33,37]$. Therefore, land classifications were manually re-coded to agricultural land uses by cross-comparison with the 2010 SEWRPC land cover data [36]. All land use measurements were converted from acres as provide by SLAMM to square meters. The percent of land uses was calculated with respect to the total area of the land cover draining into the wetlands. Values for each of the land use categories (residential, industrial, commercial, undeveloped, and agricultural) are the summation of the source subcategories (e.g. roofs, street area, parking, driveways, sidewalks and landscaped area) (Fig. 3 and 4) [38].
Predictions for pollutant loadings (nitrate + nitrite, phosphate, $\mathrm{Zn}, \mathrm{Pb}, \mathrm{Cu}$, and $\mathrm{Cd}$ ) were estimated using the geometric mean of values measured from studies reported in the literature [39-44] by the source area subcategories (e.g. roofs, street area, parking, driveways, sidewalks, and landscaped area) of each land use category (residential, industrial, commercial, undeveloped and agricultural) (Table 2). Due to the inadequacy of data the loading estimates of nitrate and metals like Ag, As, $\mathrm{Hg}$, and Ni could not be calculated. Then the total pollutant loadings in $\mathrm{Kg}$ /year were calculated by multiplying the pollutant loading estimates from the literature by the source area $\left(\mathrm{m}^{2}\right)$ subcategories (e.g. roofs, street area, parking, driveways, sidewalks, and landscaped area) of each land use category (residential, industrial, commercial, undeveloped and agricultural) in a year. This produces the total pollutant loading at each wetland site by land use category (residential, industrial, commercial, undeveloped, and agricultural) in a year. These calculated loadings are shown in Figure 4 and Table 2.

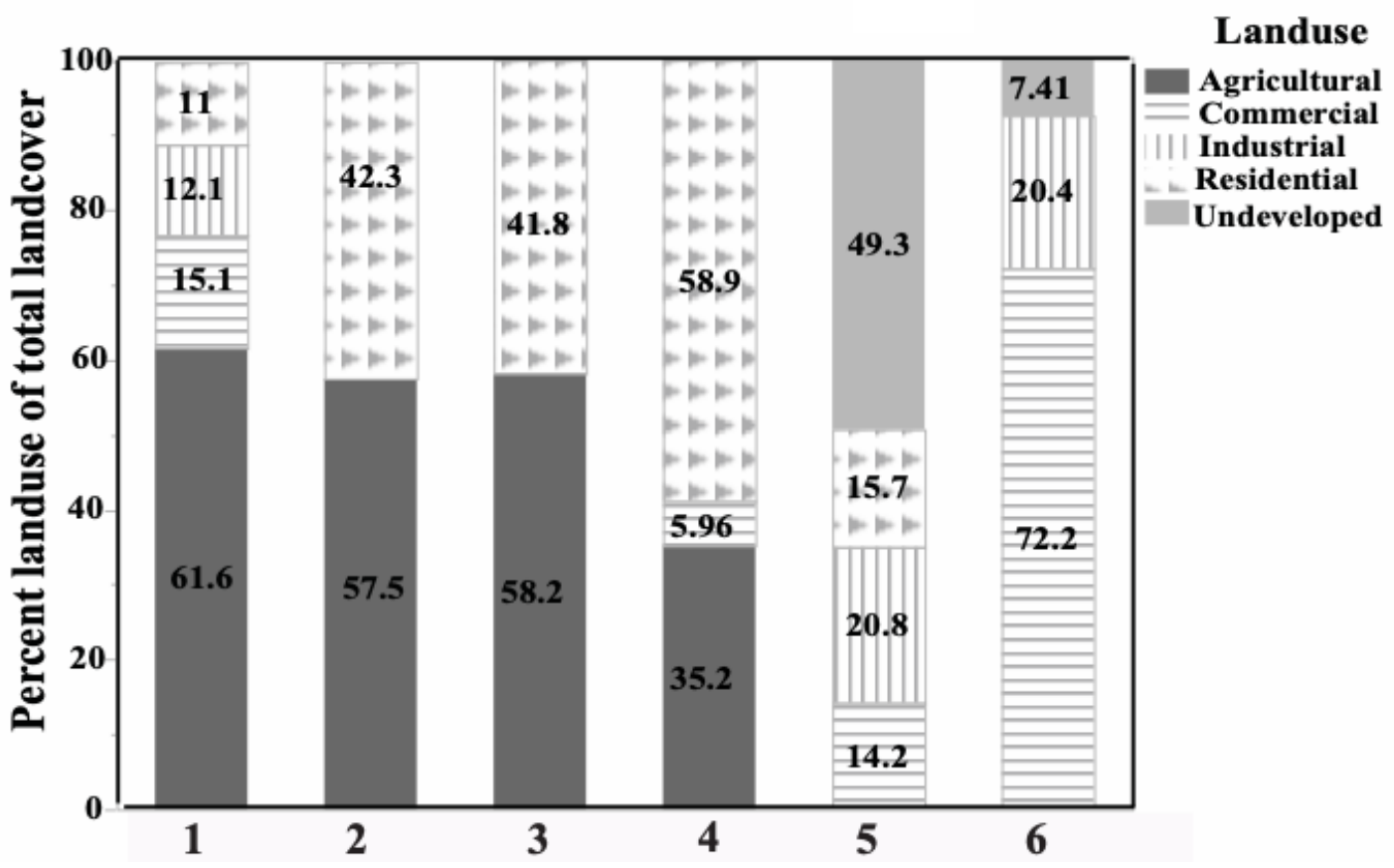

Fig. 3. Percentage of land use types for the drainage basins for the six constructed wetlands used in this study. Land use data from the Southeastern Wisconsin Regional Planning Commission

(SEWRPC) 2010, were accessed through the Racine County Map Server website.

http://racinecounty.maps.arcgis.com 


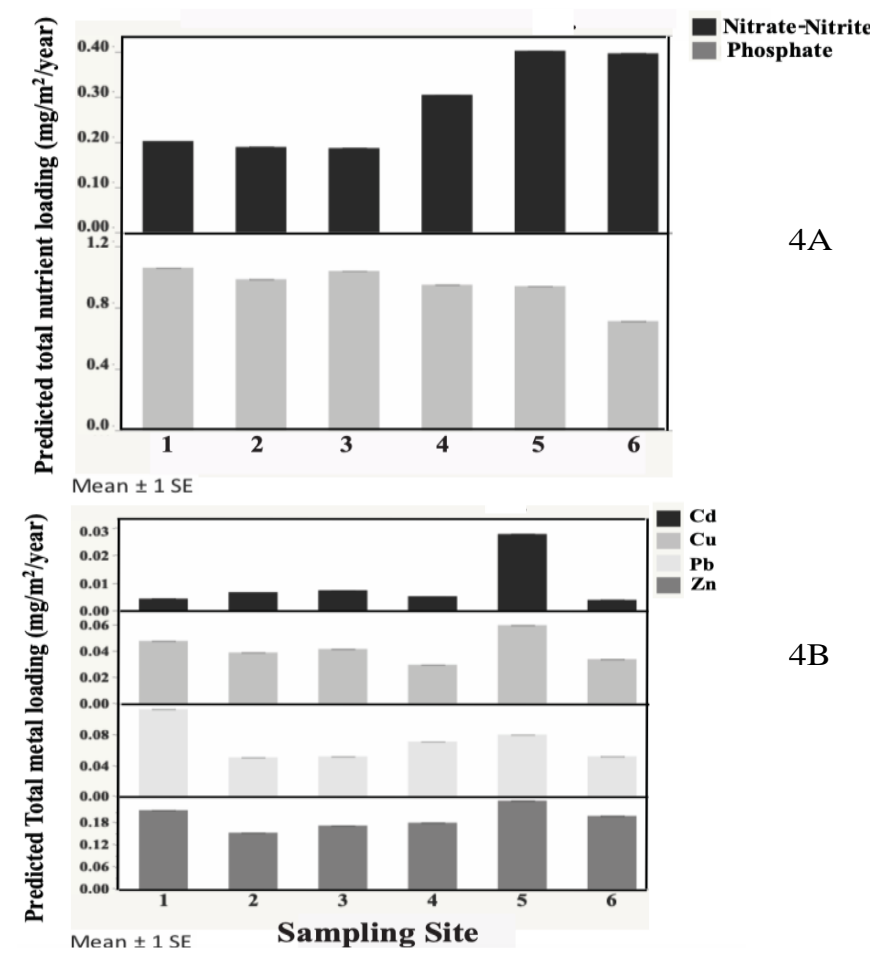

Fig. 4. (A) Predicted model of total nutrient (nitrate-nitrite and phosphate) area-weighted loadings (kg/year) from land use runoffs for wetland sites 1-6. (B) Predicted model of total metal $(\mathrm{Cd}, \mathrm{Cu}$, $\mathrm{Zn}, \mathrm{Pb}$ ) area-weighted loadings (kg/year) from land use runoffs for wetland sites 1-6

Each error bar is constructed using one standard error $( \pm 1 \mathrm{SE})$ from the mean.

Table 2. Predicted area-weighted loading and total loadings of nutrients and metals for wetland site 1-6 based upon land use and watershed area

Area Weighted Loadings $\left(\mathrm{mg} / \mathrm{m}^{2} /\right.$ year $)$

\begin{tabular}{c|ccccccc}
\hline $\begin{array}{c}\text { Wetland } \\
\text { Site }\end{array}$ & $\begin{array}{c}\text { Watershed } \\
\text { Area (ha) }\end{array}$ & $\begin{array}{c}\text { Nitrate- } \\
\text { Nitrite }\end{array}$ & Phosphate & $\mathrm{Cd}$ & $\mathrm{Cu}$ & $\mathrm{Pb}$ & $\mathrm{Zn}$ \\
\hline 1 & 104.45 & 0.21 & 1.06 & 0.00 & 0.04 & 0.11 & 0.21 \\
2 & 334.18 & 0.19 & 0.98 & 0.00 & 0.03 & 0.05 & 0.15 \\
3 & 267.46 & 0.18 & 1.04 & 0.00 & 0.04 & 0.05 & 0.17 \\
4 & 2.88 & 0.31 & 0.95 & 0.00 & 0.02 & 0.07 & 0.18 \\
5 & 493.72 & 0.41 & 0.94 & 0.02 & 0.05 & 0.08 & 0.24 \\
6 & 720.00 & 0.39 & 0.71 & 0.00 & 0.05 & 0.05 & 0.19 \\
\hline \multicolumn{7}{c}{ Total Loading from Watershed (kg/year) } \\
\hline Wetland & Watershed & Nitrate- & Phosphate & $\mathrm{Cd}$ & $\mathrm{Cu}$ & $\mathrm{Pb}$ & $\mathrm{Zn}$ \\
Site & Area (ha) & Nitrite & & & & & \\
\hline 1 & 104.45 & 2.19 & 11.07 & 0.04 & 0.41 & 1.18 & 2.24 \\
2 & 334.18 & 6.34 & 32.92 & 0.22 & 1.00 & 1.69 & 5.12 \\
3 & 267.46 & 4.81 & 27.80 & 0.19 & 1.07 & 1.38 & 4.61 \\
4 & 2.88 & 0.08 & 0.27 & 0.00 & 0.00 & 0.02 & 0.05 \\
5 & 493.72 & 20.24 & 46.34 & 1.36 & 3.46 & 3.96 & 11.87 \\
6 & 720.00 & 28.08 & 51.26 & 0.27 & 3.60 & 3.73 & 14.32 \\
\hline
\end{tabular}

\section{Sediment sampling collection}

Sediment samples were collected from the sixwetland sites. During summer 2015, a core sampler $(5 \times 50 \mathrm{~cm})$ was used to collect sediment samples to a depth of 10-15 cm from the top surface layer at three locations (two at both shorelines and the third one at the middle zone) for each wetland site. Sediments were homogenized in the field and were divided into two replicates, yielding two samples per site or a total of 12. Based upon results from the Fall 2015 samples, the sediment collection process was modified in fall 2016 and summer 2017 by using an Ekman dredge grab sampler (15 x 15 x $25 \mathrm{~cm}$ ) to gather a greater amount of sediment 
from the upper surface layer, without compressing the sediment samples [42]. In fall 2016, at each wetland site, samples were collected at two different locations from the edge zone. Sediments were homogenized in the field and were divided into three replicates, yielding three samples per site or a total of 18 . During summer 2017, two edge and two middle

\section{Ecotoxicological Assays}

Ecotoxicological tests were carried out following the standard operational procedures of the Phytotoxkit ${ }^{\mathrm{TM}}$ solid sample test (seed germination and early growth microbiotest with higher plant) developed by Microbiotest, Belgium that complies with ISO Standard 18763 for validation [28]. The Phytotoxkit ${ }^{\mathrm{TM}}$ uses three plant species: monocot Sorghum saccharatum, dicot Lepidium sativum, and Sinapis alba [28]. Control and test sediments were added and saturated with distilled water in PVC test plates $(21 \times 15.5 \times 0.8 \mathrm{~cm})$. To saturate $90 \mathrm{ml}$ of control sediment $35 \mathrm{ml}$ of distilled water was added with help of a syringe as per the reference test of Phytotoxkit ${ }^{\mathrm{TM}}$ [28]. For the test sediments, the volume of water $\left(\mathrm{V}_{\text {sat }}\right)$ needed for complete hydration of the test soil was determined by adding $50 \mathrm{ml}$ of distilled water to the soil and then subtracting the amount of supernatant recovered after saturation for every test sediment. The filter

\section{Data Analyses}

Data distributions were examined for normality and were transformed as necessary to meet the assumptions of statistical tests. Count and length data were transformed using a log zone samples were collected. This process yielded four samples per site in 2017 or a total 24. All Samples were stored in Nalgene 1-liter bottles on ice before transport to the laboratory. There were total of 54 sediment samples from all sampling times. At the laboratory, samples were stored at $-25^{\circ} \mathrm{C}$ for eco-toxicological studies.

paper was placed on top of each of the control and test sediments after saturating them with distilled water and ten seeds of the same plant were placed on the filter paper in one row and at equal distance from each other. This was repeated with all the three seed species. Plates were incubated at $25^{\circ} \mathrm{C}$ in darkness for 72 hours. Digital images were taken of all the plates, and stem and root lengths were measured using Image $J^{\mathrm{TM}}$ software [43]. The proportion of root and stem length inhibition of the test sample plants were calculated relative to the control plant growth to generate growth inhibition indices. One Phytotoxkit test TM combined the growth inhibition test plates for Sorghum saccharatum, Lepidium sativum, and Sinapis alba. Hence with 54 sediment samples, each test had 162 test plates $(54 \times 3)$. The same test was repeated twice yielding 310 sediment plates. Some sediment collected were not enough to do two tests.

transformation $(\log 10(\mathrm{X}+1))$ while proportional data were transformed using an arcsine transformation [44] before statistical analyses conducted using JMP® 14 [45].

\section{Effect of predicted nutrients and metals on Growth Inhibition}

Multifactor Analysis of variance (ANOVA) was used to examine the effects of predicted pollutants (nutrients and metals) loadings and seed species on growth inhibition of Lepidium sativum, Sinapis alba, and Sorghum saccharatum. Land use was assumed to not have changed significantly over the course of the study, and as such, the ANOVA tests for the effect of predicted loadings from the surrounding land use on the stem and root growth inhibitions (the dependent response variable) included loadings and seed species and year as independent variables. ANOVA tests for the effect of predicted loading of individual $(\mathrm{Cd}, \mathrm{Cu}, \mathrm{Pb}, \mathrm{Zn})$ metals from the surrounding land use on growth inhibition (the dependent response variable) included loadings and seed species and year as independent variables. 


\section{RESULTS AND DISCUSSION}

\section{Ecotoxicological bioindicators}

Proportion root and stem growth inhibition values are calculated relative to growth in control sediments (clean silica sand) so that positive values indicate inhibition (i.e. reduced growth $=$ inhibition) whereas negative values indicate growth stimulation (i.e. increased growth $=$ stimulation). For Lepidium sativum, root inhibition ranged from -1.5 to +1.5 and stem inhibition ranged from -0.75 to +1.25 . For Sinapis alba, root inhibition varied from -1.5 to +1.25 and stem inhibition ranged from -1 to +1.25. For Sorghum saccharatum, the proportion root inhibition ranged from -1.5 to +1.25 and stem inhibition ranged from -3.5 to +1.5. Responses varied among wetland sites and between years. Sorghum exhibited consistently higher growth inhibition for both roots and stem across the study compared to the other two-bioindicator species (Fig. 5). Wetland 1 exhibited consistently the lowest inhibition (highest stimulation) values for Lepidium sativum and Sinapis alba, whereas wetlands 3 and 4 exhibited higher inhibition (Fig. 5).

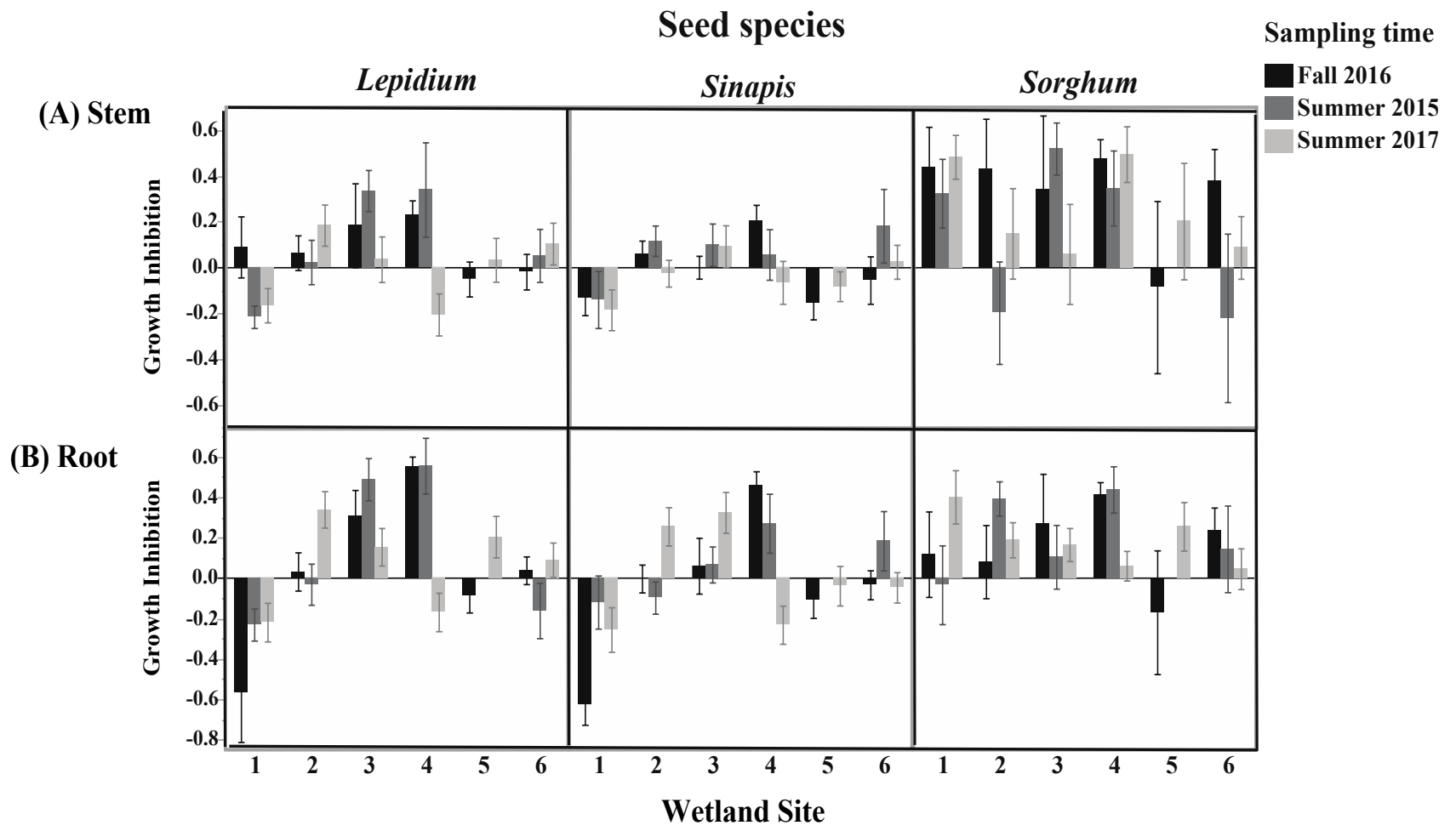

Fig. 5. Variation of growth inhibition of the bioindicator plant species (Lepidium sativum, Sinapis alba, Sorghum saccharatum) and wetland sites in three sampling dates of Fall 2016, Summer 2015, and 2017. (A) Stem Inhibition and (B) Root Inhibition. Each error bar is constructed using one standard error $( \pm 1 \mathrm{SE})$ from the mean.

\section{Ecotoxicological bioindicator, responses to pollution stress}

\section{a. Nutrient Effects}

For predicted nutrient loading ANOVA models the dependent variables were the growth inhibitions and the independent $\mathrm{x}$ variables included predicted total nutrient loadings and seed species. This model initially considered the year as an independent variable but as no significant effect of this variable was observed, the year effect was not considered in the final model (Fig. 6). This final model detected no statistically significant effects of predicted nutrient loadings or the seed species on the root growth inhibition of Lepidium sativum, Sinapis alba, Sorghum saccharatum (Fig. 6, P-values: seed species $=0.5024$, Nitrate and nitrite loading $=0.4916$, phosphate loading $=0.8761$, nutrient interaction $=0.9162$ ). Although with an increase in the nitrate + nitrite and phosphate loading decrease in the root growth inhibition was observed. This suggests that the root inhibition was negatively affected by the 
predicted nutrient loadings. There were significant results for stem growth inhibition. There was a significant effect of the seed species $(\mathrm{P}<0.0001)$ with the highest inhibition in Sorghum saccharatum, nitrate and nitrite loading $(\mathrm{P}=0.0041)$, and the nutrient interaction $(\mathrm{P}=0.0116)$ on stem growth inhibition of Lepidium sativum, Sinapis alba,
Sorghum saccharatum. However, the effect of phosphate loading was not significant for stem growth inhibition $(\mathrm{P}=0.0898)$ (Fig. 6). Stem growth inhibition was observed to be decreasing with nitrate and nitrite loading, but increasing with phosphate loading (Fig. 6). Implying the negative effect of nitrate and nitrite loading on the stem growth inhibitions.
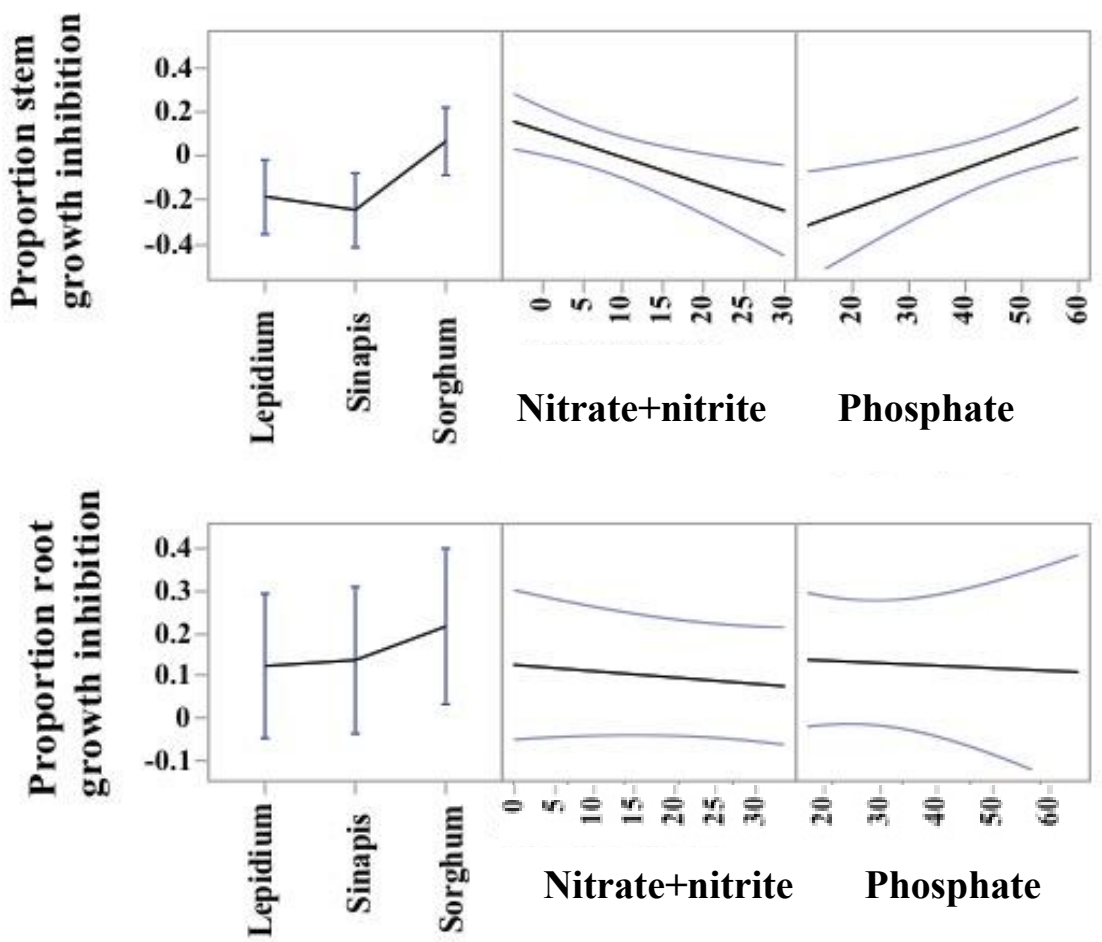

\section{Seed Species $\quad$ Predicted total nutrient loading $(\mathrm{Kg} / \mathrm{year})$}

Fig. 6. Prediction profiles from ANOVA showing the effects of seed species and the predicted total loadings of total nitrate + nitrite and phosphate ( $\mathrm{kg} / \mathrm{year}$ ) on the growth inhibitions of stems and roots for the bioindicator species Lepidium sativum, Sinapis alba, Sorghum saccharatum. The bluelined area in each profile represents the $95 \%$ confidence prediction interval of the response variable.

The profiler is set for nitrate + nitrite at $1.96 \mathrm{~kg} /$ year, phosphate at $26.23 \mathrm{~kg} /$ year in case of root growth inhibition, and nitrate + nitrite at $10.91 \mathrm{~kg} / \mathrm{year}$, phosphate at $26.23 \mathrm{~kg} /$ year in case of stem growth inhibition.

\section{b. Metal Effects}

For predicted metal loading ANOVA models the dependent variables were the growth inhibitions and the independent $\mathrm{x}$ variables included predicted total metal loadings and seed species. This model initially considered the year as an independent variable but as no significant effect of this variable was observed, the year effect was not considered in the final model (Fig. 7). The effects of heavy metal loadings predicted by the land cover on root inhibition were not statistically significant except for $\mathrm{Pb}$
(Fig. 7). P-values for root inhibition: seed species $=0.4359, \mathrm{Cd}$ loading $=0.3064, \mathrm{Cu}$ loading $=0.9990 . \mathrm{Pb}$ loading $=0.0168, \mathrm{Zn}$ loading $=0.6119$, metal loading interactions $=$ 0.4625). Decreased root inhibition (i.e. facilitated root growth) was associated with an increase in $\mathrm{Pb}$ loading (Figure 7). Likewise, the effects of heavy metal loadings predicted by land cover on stem inhibition were not significant (P-values for effect on stem inhibition: $\mathrm{Cd}$ loading $=0.3167, \mathrm{Cu}$ loading $=$ 
0.6489, $\mathrm{Pb}$ loading $=0.1512, \mathrm{Zn}$ loading $=$ 0.9076, metal loading interaction $=0.4629$ ). Suggesting that suggest that the Pb loading as predicted (in $\mathrm{Kg} /$ year) in these wetland sites (16) did not affect these three plant bioindicator species of Lepidium sativum, Sinapis alba, and
Sorghum saccharatum negatively. Seed species responded differently to predicted metal loadings. For stem inhibition, the effect of seed species effect was significant $(\mathrm{P}<.0001)$ with highest inhibition observed in Sorghum saccharatum (Fig. 7).
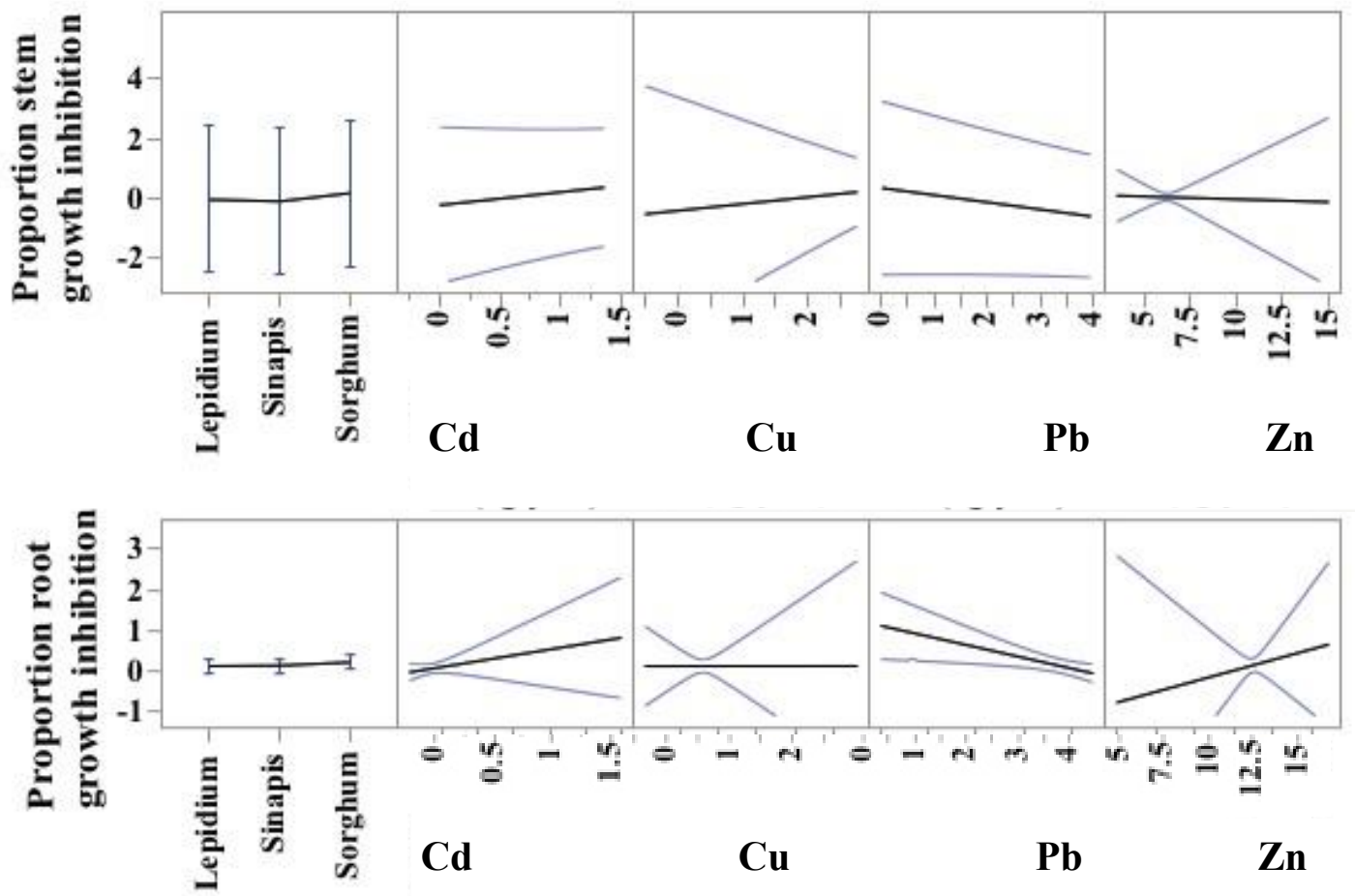

Seed Species $\quad$ Predicted total metal loading (Kg/year)

Fig. 7. Prediction profiles from ANOVA showing the effect of predicted total loading of $\mathrm{Cd}, \mathrm{Cu}$, $\mathrm{Zn}, \mathrm{Pb}$ in $\mathrm{kg} /$ year on the growth inhibitions of the bioindicator species Lepidium sativum, Sinapis alba, Sorghum saccharatum. The blue-lined area in each profile represents the $95 \%$ prediction confidence interval for the response variable. The profiler is set to $\mathrm{Cd}$ at $1.26 \mathrm{~kg} / \mathrm{year}, \mathrm{Cu}$ at 1.43 $\mathrm{kg} /$ year, $\mathrm{Pb}$ at $1.88 \mathrm{~kg} /$ year and $\mathrm{Zn}$ at $6.04 \mathrm{~kg} /$ year in case of root growth inhibition and $\mathrm{Cd}$ at 1.25 $\mathrm{kg} /$ year, $\mathrm{Cu}$ at $1.36 \mathrm{~kg} /$ year, $\mathrm{Pb}$ at $1.88 \mathrm{~kg} /$ year and $\mathrm{Zn}$ at $13.85 \mathrm{~kg} /$ year in case of stem growth inhibition.

This study was designed to explore the potential of PhytoTox ${ }^{\mathrm{TM}}$ ecotoxicological tests to serve as possible bioindicators for predicted pollution loading from surrounding land uses for wetland ponds located in urbanizing watersheds. Agricultural and residential land uses both produce runoffs rich in nutrients such as phosphate and nitrate due to the presence of fertilizers and pesticides applied to lawns, gardens, and agricultural fields. These fertilizers and pesticides especially when rich in nutrients affect plant growth [46-54]. The predicted loadings were a constant measure over a while (a year). The results suggest a possibility of interactions between the loadings of nutrients (e.g. from fertilizers) and loadings of metals associated with these pesticides resulting in various levels responses from Lepidium sativum, Sinapis alba, Sorghum saccharatum such as root inhibition was negatively affected by the predicted nutrient loadings, the negative effect of nitrate + nitrite loading on the stem growth inhibitions but the $\mathrm{Pb}$ loading as predicted (in $\mathrm{Kg} /$ year) in these wetland sites (16) did not affect negatively.

The factors contributing to the differing responses by the different ecotoxicological bioindicator plant species is grounds for further 
study. As in this paper, herbicides and metals are well-known to affect the growth and development of Sorghum saccharatum [49, 54]. In comparison, however, Sinapis alba and

\section{CONCLUSIONS}

One of the challenges for monitoring environmental impacts in terms of the Clean Water Act is to identify and develop indicators that can capture and integrate the effects of pollutants or stressors across various (sometimes mismatched) spatial and temporal scales. Chronic stressors such as baseline nutrient loading from agricultural fields provide fundamentally different signals to detect compared to acute events such as a manure spill or pesticide application whose detection by direct chemical measurement may be missed between monitoring sessions. The situation is made more complicated by the fact that interactions among different stressors in nature may result in complex response patterns that can result in the interpretation of the patterns

\section{ACKNOWLEDGEMENTS}

This work was supported by the Village of

\section{REFERENCES}

[1] WANG, L. and LYONS, J., Biological Response Signatures: Indiactor Patterns Using Aquatic Communities, CRC Press, 2003, p. 227.

[2] EPA, Protecting Water Quality from Urban Runoff, United States Environ. Prot. Agency, no. 2 ,

2003, p. EPA-841-F-03-003.

[3] FOLEY, J. A., DEFRIES, R., ASNER G. P., BARFORD, C, BONAN, G., CARPENTER, S. R., CHAPIN, F. S., COE, M. T., DAILY, G. C, GIBBS, H. K., HELKOWSKI, J. H., HOLLOWAY, T., HOWARD, E. A., KUCHARIK C. J., MONFREDA, C, PATZ, J. A., PRENTICE, I. C, RAMANKUTTY, N., SNYDER, P. K., Science (80), 309, no. 5734, 2005, p.

570.

[4] CAREY, R., HOCHMUTH, G. J., Hort Technol., 22, no. 4, 2012, p. 418.

[5] EPA, Summary of the Clean Water Act., 2012.

[6] GLICKSMAN, R. L., BATZEL, M. R., Washingt. Univ. J. Law Policy, Washingt.
Lepidium sativum frequently exhibited negative inhibition (stimulation) for root and stem growth in this paper.

detected being very context-dependent.

The results of this paper provide signals of stress from watershed pollutants draining into the wetland sites, which should be further explored with real measurements in the wetland sites (1-6). A major character of a biological sub-metrics that it should be able to detect biological responses to human activities across different scales, these ecotoxicological bioindicators demonstrated evidence of stress across different spatial scales of six different wetlands. We estimated the chemical risk (nutrient and metals) with the use of plant ecotoxicological bioindicators. Our results detected a correlation in the ecotoxicological bioindicators with watershed pollutants that were predicted.

Mount pleasant (Racine, WI).

Univ. Sch. Law, 32, 2010, p. 99.

[7] CAIRNS, J.J., PRATT, J. R., Freshwater Biomonitoring and Benthic Macroinvertebrates, Chapman and Hali, New York, 1993, p. 10-27.

[8] KARR, J. R., Measuring Biological integrity: lesions from stream, in S. Woodley, J. Kay and G. Francis (Eds.), in Ecological Integrity and Management of Ecosystems, Delray, FL: St. Lucie Press, 1993.

[9] KARR, J. R., Predicting Aquatic ecosystems: clean water is not enough, in W.S Davis and T.P. Simon(Eds.), in Biological Assessment and Criteria: Tools for Water Resource Planning and Decision Making., Boca Raton, FL: Lewis Publishers, 1995, p. 7-13.

[10] YODER, C, RANKIN, E., Biological response signatures and the area degradation value: new tools for interpreting multi-metric data, in W.S. Davis and T.P. Simons(Eds), in Biological Assessment and Criteria: Tools for Water Resource Planning and Decision Making., Boca Raton,

FL: Lewis Publishers, 1995, p. 263-286.

[11] YODER, C, RANKIN, E., Biological 
criteria program development and implementation in Ohio in W.S. Ohio and T.P.Simon (Eds.), in Biological Assessment and Criteria: Tools for Water Resource Planning and Decision Making., Boca Raton, FL: Lewis Publishers, 1995, p. 109-144.

[12] CLAPCOTT, J. E., GOODWIN, E. O., YOUNG, R G, KELLY, D. J., Knowl. Manag. Aquat. Ecosyst., 2014, no. 415.

[13] ClAPCOTT, J. E., COLlIER, K. J., DEATH, R G, GOODWIN, E. O., HARDING, J. S., KELLY, D., LEATHWICK, J. R, YOUNG, R. G, Freshw. Biol., 57, no. 1, 2012, p. 74.

[14] TIXIER, G., ROCHFORT, Q., GRAPENTINE, L., MARSALEK, J., LAFONT, M., Water Res., 46, no. 20, 2012, p. 6671.

[15] KADLEC, R, WALLACE, S., Treatment Wetlands. CRC Press Taylor \& Francis Group, LLC, 2009.

[16] MANIOS, T., FOUNTOULAKIS, M., KARATHANASIS, A., Environ. Manage., 43, no. 5, 2009, p. 908.

[17] SCHOLZ, M., HEDMARK, A., Water. Air. Soil Pollut, 205, no. (1-4), 2010, p. 323.

[18] BEUTEL, M., MORGAN, M., ERLENMEYER, J., BROUILLARD, E., J. Environ. Qual., 43, no. 3, 2014, p. 1071.

[19] KHAN, S., AHMAD, I., SHAH. M., REHMAN, S., KHALIQ, A., J. Environ. Manag., 90, no. 11, 2009, p. 3451.

[20] KNOX, A., NELSON, E., HALVERSON, N., GLADDEN, J., Soil Sediment Contam., 19, no. 6, 2010, p. 667.

[21] SAHU, O., Int. Lett. Nat. Sci., 12, 2014, p. 35.

[22] KARR, J. R., CHU, E. W., Restoring Life in Running Waters, Island Press, Washington D.C., Covelo California, 1999.

[23] AYLAGAS, E., BORJA, A., TANGHERLINI, M., DELL'ANNO, A., CORINALDESI, C, MICHELL, C. T., Mar. Pollut. Bull, 114, no. 2, 2017, p. 679.

[24] KE, X., WANG, C, JING, D., ZHANG, Y., ZHANG, H, Mar. Pollut. Bull., 98, 2015, p. 267.

[25] CHAPMAN, D. P. M., Environ. Toxicol. Chem., 14, no. 9, 1995, p. 1451.

[26] JENSEN, J., Sediment toxicity and the recovery of biological integrity in a restored stream channel. Milwaukee., University of
Wisconsin Milwaukee, 2011.

[27] DELLINGER, M., CARVAN, M., KLINGER, K, McGRAW, J., EHLINGER, T., Challenges, 5, no. 1,2014, p. 75.

[28] MICROBIOTEST Inc, Standard Operational Procedure, Phytotoxkit. Seed germination and early growth microbiotest with higher plants, Available from: https://www.microbiotests.com_[08.31.2020]. [29] CZERNIAWSKA-KUSZA, I., KUSZA, G, Environ. Monit. Assessment., 179, no. 1-4, 2010, p. 113.

[30] CZERNIAWSKA-KUSZA, I., CIESIELCZUK, T., KUSZA, G., CICHON, A., Environ. Toxicol, 21, no. 4, 2006, p. 367.

[31] PERSOONE, G., VANGHELUWE, M., Toxicity determination of the sediments of the river Seine in France by application of a battery of microbiotests. New York: New Microbiotests for Routine Toxicity Screening and Biomonitoring, Kluwer Academic, 2000.

[32] SIMS, A., ZHANG, Y., GAJARAJ, S., BROWN, P., HU, Z., Water Res., 47, no. 5, 2013, p. 1711.

[33] CRISPELL-SYNDER, I., Executive summary of WDNR facilitation presentation for Pike River improvements by Mount Pleasant Storm Water Drainage District No. 1., 1997.

[34] EHLIGER, T., DeTHORNE, L., BERNER, B., Monitoring of stream habitat and aquatic biotic integrity - Pike River North and South Branches, Racine and Kenosha Counties, Wisconsin, 2002.

[35] EHLIGER, T., DeTHORNE, L., Monitoring of stream habitat and aquatic biotic integrity -Pike River North and South Branches, Racine and Kenosha Counties, Wisconsin, Interim Report., 2004.

[36] Southeastern Wisconsin Regional Planning Commission, SEWRPC, Racine County Mapbook, 2010.

[37] PITT, R., VOORHEES, J., The Source Loading and Management Model (SLAMM), A Water Quality Management Planning Model for Urban Stormwater Runoff., 2000.

[38] PITT, R., VOORHEES, J., Source loading and management model (SLAMM). Seminar Publication: National Conference on Urban Runoff Management: Enhancing Urban Watershed Management at the Local, County, and State Levels March 30 - April 2, 1993, Cent. Environ. Res. Information, U.S. Environ. 
Prot. Agency. EPA/625/R-95/003. Cincinnati. Ohio., 1995, p. 225-243. [39] PITT, R., BOZEMAN, M., Sources of Urban Runoff Pollution and Its Effects on an Urban Creek., Cincinnati, OH., 1982.

[40] BANNERMAN, R. T., OWENS, D. W., DODDS, R. B., HORNEWER, N. J., Water Sci. Technol., 28, no. 3-5, 1993, p. 241.

[41] BANNERMAN, R., BAUN, K., BOHN, P., GRACZYK, D., Evaluation of Urban Nonpoint Source Pollution Management in Milwaukee County, Wisconsin., Chicago, IL, 1983. [42] KASICH, J. T., NELLY, M., SCOTT, J., Sediment Sampling Guide and Methodologies., Ohio EPA Sediment Sampl. Guid. Environ. Prot. Agency., 2012.

[43] SCHEIDER, C. A., RASBAND, W. S., ELICEIRI, K. W., Nat. Methods, 9, no. 7, 2012, p. 671.

[44] SOKAL, R., ROHLF, J., BIOMETRY, Second. San Fransisco: W.H. Freeman and Company, 1981.

[45] SAS, JMP®, Version <14>, SAS Institute Inc., Cary, NC, 2019.

[46] ALTIERI, M. A., NICHOLLS, C. I., Soil Tillage Res., 72, no. 2, 2003, p. 203.
[47] CHEN, B. M., WANG, Z. H., LI, S. X., WANG, G. X., SONG, H. X., WANG, X. N., Plant Sci., 167, no. 3, 2004, p. 635.

[48] SCHEIRS, J., BRUYN De, L. De, Entomol. Exp. Appl., 113, no. 2, 2004, p. 109. [49] LOPEZ-LUNA, J., GONZALEZCHAVEZ, M., ESPARZA-GARCIA, F., RODRIGUEZ-VAZQUEZ, R., J. Hazard. Mater., 163, no. 2-3, 2009, p. 829.

[50] PANG, J., RYAN, M. H., TIBBETT, M., CAWTHRAY, G. R., SIDDIQUE, K. H. M., BOLLAND, M. D. A., DENTON, M. D., LAMBERS, H., Plant Soil, 331, no. 1, 2010, p. 241. [51] LIU, C. W., SUNG, Y., CHEN, B. C, LAI, H. Y., Int. J. Environ. Res. Public Health, 11, no. 4, 2014, p. 4427.

[52] ZHAWAR, V. K., KAUR, N., GUPTA, A. K., J. Plant Nutr., 37, no. 13, 2014, p. 2195.

[53] SHUKLA, D., RINEHART, C. A., SAHI, S. V., Sci. Rep., 7, no. 1, 2017, p. 1.

[54] GERIK, T., BEAN, B., VANDERLIP, R., Sorghum Growth and Development. Texas., Texas A M Univ. Syst, http://glasscock.agrilife.org/files/2015/05/Sorgh um-Growth-and-Development.pdf, 2010. 